\title{
Effective use of atomoxetine to treat six inpatient youths with disruptive mood dysregulation disorder without attention deficit disorder
}

\author{
Xavier Benarous, ${ }^{1,2 *}$ (1) Vladimir Ferrafiat, ${ }^{3,4}$ Jessica Zammit, ${ }^{3,4}$ Angèle Consoli, ${ }^{1,5}$ \\ Priscille Gérardin, ${ }^{3,4}$ Jean-Marc Guilé, ${ }^{2,6,7}$ and David Cohen ${ }^{1,8}$
}

\footnotetext{
${ }^{1}$ Department of Child and Adolescent Psychiatry, Pitié-Salpêtrière Hospital, Sorbonne University, Paris, France

${ }^{2}$ INSERM U1105 Research Group for Analysis of the Multimodal Cerebral function, University of Picardie- Jules Verne (UPJV), Amiens, France

${ }^{3}$ Department of Child and Adolescent Psychiatry, Charles Nicolle Hospital, Rouen, France

${ }^{4}$ Department of Child and Adolescent Psychiatry, URHEA, CH Le Rouvray, Sotteville les Rouen, France

${ }^{5}$ Group of Clinical Research-15, Dimensional approach of child and adolescent psychotic episodes, Sorbonne University, Paris, France

${ }^{6}$ Child and Adolescent Psychiatry Services, Amiens University Hospital, Amiens, France

${ }^{7}$ Department of Psychiatry, McGill University, Montreal, Canada

${ }^{8}$ CNRS UMR 7222, Institute for Intelligent Systems and Robotics, Sorbonnes Universités, UPMC, Paris, France
}

Received 20 March 2019; Accepted 9 April 2019

Key words: Atomoxetine, Disruptive Mood Dysregulation Disorder, Chronic irritability, Depressive Disorders, inhibitor of the norepinephrine transporter.

\section{Introduction}

Despite the significant disease burden associated with disruptive mood dysregulation disorder (DMDD), very little is known about effective treatments. ${ }^{1}$ Atomoxetine (ATX) is a nonstimulant presynaptic inhibitor of the norepinephrine (NE) transporter. Current pharmacological guidelines suggest that ATX should be considered as a second-line treatment for ADHD, especially when anxiety or mood disorder co-occurred. ${ }^{2}$ While the efficacy of ATX on affective symptoms has never properly been investigated in children or adolescents, two meta-analyses of RCTs in adults with ADHD showed its positive impact on emotional lability in addition to ADHD symptoms. ${ }^{3,4}$ In children and adolescents, anecdotic reports stress a possible positive impact of ATX in patients with neurodevelopmental disorder associated with cognitive difficulties, such as sluggish cognitive tempo, dyslexia, and pervasive developmental disorder. ${ }^{5}$ Recently, based on evidence mainly from adult patients, we used ATX in six resistant inpatient cases with severe chronic irritability and matching DMDD criteria. Five showed a dramatic clinical improvement.

\footnotetext{
*Address correspondence to: Xavier Benarous, Department of Child and Adolescent Psychiatry, Pitié-Salpêtrière Hospital, 83, boulevard de l'Hôpital, 75013 Paris, France. Tel: +33(0)142162380, Fax: +33(0) 142162331. (Email: xavierbenarous@gmail.com)
}

\section{Methods}

We conducted a retrospective review of psychiatric inpatients who were challenged with ATX for the management of DMDD between October 2016 and October 2018 in two child and adolescent psychiatric departments in tertiary care university hospital. Given the large overlap between ADHD and DMDD symptoms (50$80 \%$ ), only youths with DMDD and without ADHD diagnosis were eligible. By doing so, we ensured that the treatment efficacy could not be due to the effect of ATX on ADHD symptoms. DMDD diagnosis was established from symptoms reported by the patient and his/her family. Psychiatric diagnoses were based on discharge diagnoses after the assessment of all information available. Clinical improvement was based on clinical measures routinely used in both departments: (i) the Clinical Global Impression Improvement scale (CGI-I), (ii) the difference in the Affective Reactivity Index score (ARI), the Buss-Durkee Hostility Inventory score (BDHI), and the Children-Global Assessment Functioning (C-GAF) at entrance and at discharge; (iii) changes in the number of weekly physical restraints; and finally (iv) changes in the number of weekly as needed (PRN) medications. To determine the specific impact of the medication, we defined the week prior to ATX initiation as the baseline period for the weekly use of physical restraints and PRN medications. Changes were assessed and reported 


\section{Table 1. Case descriptions}

\begin{tabular}{|c|c|c|c|c|c|c|c|c|c|c|c|c|}
\hline Patient & $\begin{array}{l}\text { Age ( } y=\text { years, } \\
m=\text { months) }\end{array}$ & Gender & Diagnoses associated with DMDD & $\begin{array}{l}\text { C-GAF } \\
\text { at } \\
\text { entrance }\end{array}$ & $\begin{array}{l}\text { CGI-S at } \\
\text { entrance }\end{array}$ & $\begin{array}{l}\text { Medication } \\
\text { history before } \\
\text { hospitalization }\end{array}$ & $\begin{array}{l}\text { Medications } \\
\text { at discharge }\end{array}$ & $\begin{array}{l}\text { ATX } \\
\text { initial } \\
\text { dose }\end{array}$ & $\begin{array}{c}\text { Titration } \\
\text { duration for full } \\
\text { dose treatment }\end{array}$ & $\begin{array}{c}\text { ATX } \\
\text { discharge } \\
\text { dose }(\mathrm{mg} / \\
[\mathrm{kg} / \mathrm{d}])\end{array}$ & Follow-up & $\begin{array}{l}\text { Confounding } \\
\text { medication } \\
\text { changes }\end{array}$ \\
\hline 1 & $14 y 0 m$ & M & $\begin{array}{l}\text { ANX: panic disorder } \\
\text { MLD: dyspraxia + dyslexia } \\
\text { IQ } 100\end{array}$ & 25 & 6 & $\begin{array}{l}\text { RIS, HAL, CYA, } \\
\text { LOX }\end{array}$ & $\begin{array}{l}\text { ATX } 80 \mathrm{mg} \\
\quad \text { qam } \\
\text { LVP tid } \\
\text { DVP bid }\end{array}$ & $\begin{array}{l}10 \mathrm{mg} / \\
\mathrm{d}=0.13 \\
\mathrm{mg} / \mathrm{kg} / \mathrm{d}\end{array}$ & 4 weeks & $\begin{array}{l}80 \mathrm{mg} / \\
\mathrm{d}=0.95 \mathrm{mg} / \\
\mathrm{kg} / \mathrm{d}\end{array}$ & 5 months & Minor \\
\hline 2 & $12 y 7 m$ & $\mathrm{~F}$ & $\begin{array}{l}\text { ANX: } \\
\text { MLD: dyspraxia + dyscalculia + } \\
\text { dysorthography } \\
\text { no } I Q \text { available }\end{array}$ & 30 & 6 & RIS, ARI, CAR, & ATX $80 \mathrm{mg}$ & $\begin{array}{l}25 \mathrm{mg} / \\
\mathrm{d}=0.4 \\
\mathrm{mg} / \mathrm{kg} / \mathrm{d}\end{array}$ & 4 weeks & $\begin{array}{l}80 \mathrm{mg} / \\
\mathrm{d}=1.2 \mathrm{mg} / \\
\mathrm{kg} / \mathrm{d}\end{array}$ & 10 months & None \\
\hline 3 & $11 \mathrm{y} 9 \mathrm{~m}$ & M & $\begin{array}{l}\text { ANX: } \\
\text { MLD: } \\
\text { dyslexia + dyspraxia + dyscalculia + } \\
\quad \text { dysorthography } \\
\text { Chromosome aneuploidies } 47, \mathrm{XYY} \text { ) } \\
\text { borderline cognitive function }\end{array}$ & 25 & 6 & $\begin{array}{l}\text { RIS, CAR, MEL, } \\
\text { CYA, }\end{array}$ & $\begin{array}{l}\text { ATX } 50 \mathrm{mg} \\
\text { MEL } 2 \mathrm{mg}\end{array}$ & $\begin{array}{l}25 \mathrm{mg} / \\
\mathrm{d}=0.71 \\
\mathrm{mg} / \mathrm{kg} / \mathrm{d}\end{array}$ & 4 weeks & $\begin{array}{l}40 \mathrm{mg} / \\
\mathrm{d}=1.14 \mathrm{mg} / \\
\mathrm{kg} / \mathrm{d}\end{array}$ & 48 months & None \\
\hline 4 & $10 y 4 m$ & $\mathrm{~F}$ & $\begin{array}{l}\text { ANX; } \\
\text { Dyspraxia } \\
\text { no IQ available }\end{array}$ & 30 & 5 & RIS, LOX, & $\begin{array}{l}\text { ATX } 60 \mathrm{mg} \\
\text { MEL } 2 \mathrm{mg}\end{array}$ & $\begin{array}{l}25 \mathrm{mg} / \\
\mathrm{d}=0.55 \\
\mathrm{mg} / \mathrm{kg} / \mathrm{d}\end{array}$ & 4 weeks & $\begin{array}{l}60 \mathrm{mg} / \\
\mathrm{d}=1.33 \mathrm{mg} / \\
\mathrm{kg} / \mathrm{d}\end{array}$ & 24 months & None \\
\hline 5 & $10 y 7 m$ & M & $\begin{array}{l}\text { ANX: MLD: dyslexia + dyspraxia + } \\
\text { dyscalculia + dysorthography } \\
\text { IQ: } 70\end{array}$ & 30 & 5 & LAM, DVP, LVP & ATX $30 \mathrm{mg}$ & $\begin{array}{l}10 \mathrm{mg} / \\
\mathrm{d}=0.4 \\
\mathrm{mg} / \mathrm{kg} / \mathrm{d}\end{array}$ & 3 weeks & $\begin{array}{l}60 \mathrm{mg} / \\
\mathrm{d}=1.2 \mathrm{mg} / \\
\mathrm{kg} / \mathrm{d}\end{array}$ & 7 months & None \\
\hline 6 & $11 \mathrm{y} 2 \mathrm{~m}$ & M & $\begin{array}{l}\text { ANX: } \\
\text { MLD: dysorthography + dyspraxia } \\
\text { ASD } \\
\text { IQ: } 107\end{array}$ & 25 & 6 & RIS, ARI, SER, & ATX $60 \mathrm{mg}$ & $\begin{array}{l}25 \mathrm{mg} / \\
\mathrm{d}=0.57 \\
\mathrm{mg} / \mathrm{kg} / \mathrm{d}\end{array}$ & 5 weeks & $\begin{array}{l}60 \mathrm{mg} / \\
\mathrm{d}=1.36 \mathrm{mg} / \\
\mathrm{kg} / \mathrm{d}\end{array}$ & 6 months & None \\
\hline
\end{tabular}

Notes: DMDD, disruptive mood dysregulation disorder; ANX, anxiety disorder; MLD, multiple learning disabilities; CYA, cyamemazine; RIS, risperidone; ARI, aripiprazole; HAL, haloperidol; LOX, loxapine; ATX, atomoxetine; LVP, levomepromazine; DVP; divalproex sodium; CAR, carbamazepine; LAM, lamotrigine; SER, sertraline; MEL, melatonine.

Major, antipsychotic cross taper conducted; Minor, tapered off ineffective antipsychotic with no new drug started. 
at 2, 3 and 4 weeks following achievement of concentration steady state at the maximum used ATX dosage. This project was designated as Institutional Review Board (IRB) exempt due to its retrospective design, patient de-identification, and the use of routine questionnaires.

\section{Results}

Six patients aged from 10 to 14 years (mean 11.7 ) were included (Table 1$)$. Most patients were male $(n=4)$. The most common associated diagnoses with DMDD was anxiety disorder $(n=6)$. Five patients had multiple learning disabilities. The period of treatment on ATX ranged from 5 to 48 months (mean 16.7). Mean ATX starting dosage was $20 \mathrm{mg} / \mathrm{d}$ (i.e., $0.46 \mathrm{mg} / \mathrm{kg} / \mathrm{d}$ ) and mean discharge dosage was $63 \mathrm{mg} / \mathrm{d}$ (i.e., $1.20 \mathrm{mg} / \mathrm{kg} / \mathrm{d}$ ). The number of weeks to achieve maximum dose ranged from 3 to 5 weeks (mean 4 ).

During the hospitalization, the score on the G-GAF showed improvement, with average change value of +50.8. Five patients were very much improved and one patient was minimally improved according to the CGI-I following ATX therapy. We noted a $73 \%$ reduction of the ARI scores (at entrance mean $=24( \pm 2.53)$, at discharge mean $=6.68( \pm 6.49), t(5)=7.61, p<.001)$ and a $46 \%$ decrease of the BDHI scores (at entrance mean $=102.2( \pm 13.6)$, at discharge mean $=54.5( \pm 19.5)$, $t(5)=8.27, p<.001)$.

The use of physical restraints for aggressive behavior was reduced during the treatment period (mean $=7.67$ at baseline compared to mean $=4.17$ after 2 weeks, $p=.01)$. The frequency of PRN medications per week decreased after 2 weeks of ATX (mean $=4.83$ at baseline compared to mean $=3.67$ after 2 weeks, $p=.02$ ). No patients were readmitted to our facility within 60 days following discharge. ATX was well tolerated. The main adverse effect identified was enuresis in one patient.

\section{Discussion}

We found that five patients were very much improved and one patient minimally improved following ATX therapy. These observations are supported by the reduction of ARI and BDHI scores between admission and discharge, and by the decrease in physical restraints and PRN medications in the weeks following achievement of concentration steady state at the maximum used ATX dosage. As mentioned in the introduction, the assumption that
ATX could have a positive effect on emotional dysregulation symptoms was based on empirical data from adults with $\mathrm{ADHD} .^{3,4}$ The most striking finding of this study is that ATX could also effectively target irritability in non-ADHD youths. Open-label use of medications, the small sample size, the use of other medications, and the absence of blind clinical rating limit our ability to produce firm conclusions. Moreover, all of the six patients had at least one comorbid anxiety disorder. Such finding may partially explain the efficacy of ATX toward chronic irritability by reducing anxiety features. However, we believed that ATX should be investigated through well-designed efficacy and tolerance studies on DMDD in children and adolescents to confirm or reject our observations.

\section{Disclosures}

The authors declare they have nothing to disclose.

\section{Acknowledgment}

We thank our residents and the medical secretaries who kindly helped to provide the necessary data for our analysis.

\section{Funding}

No grant was received for this research.

\section{REFERENCES:}

1. Benarous X, Consoli A, Guile JM, et al. Evidence-based treatments for youths with severely dysregulated mood: a qualitative systematic review of trials for SMD and DMDD. Eur Child Adolesc Psychiatry. 2017; 26(1): 5-23; doi: 10.1007/s00787-016-0907-5.

2. NICE. National Institute for Health and Care Excellence: Guidance. Attention Deficit Hyperactivity Disorder: Diagnosis and Management (NG87). Leicester: The British Psychological Society \& The Royal College of Psychiatrists; 2018.

3. Moukhtarian TR, Cooper RE, Vassos E, et al. Effects of stimulants and atomoxetine on emotional lability in adults: a systematic review and meta-analysis. Eur Psychiatry J Assoc Eur Psych. 2017; 44: 198-207; doi: 10.1016/j.eurpsy.2017.05.021.

4. Lenzi F, Cortese S, Harris J, et al. Pharmacotherapy of emotional dysregulation in adults with ADHD: a systematic review and metaanalysis. Neurosci Biobehav Rev. 2018; 84: 359-367; doi: 10.1016/ j.neubiorev.2017.08.010.

5. Jou RJ, Handen BL, Hardan AY. Retrospective assessment of atomoxetine in children and adolescents with pervasive developmental disorders. J Child Adolesc Psychopharmacol. 2005; 15(2): 325-330; doi: 10.1089/cap.2005.15.325. 